\title{
Construction and characterization of a genomic BAC library for the Mus m. musculus mouse subspecies (PWD/Ph inbred strain) Petr Jansa, Petr Divina and Jiř́i Forejt*
}

Address: Institute of Molecular Genetics, Academy of Sciences of the Czech Republic and Center for Applied Genomics, Vídeňská 1083, CZ-142 20, Prague 4, Czech Republic

Email: Petr Jansa - pjansa@biomed.cas.cz; Petr Divina - divina@biomed.cas.cz; Jiří Forejt* - jforejt@biomed.cas.cz

* Corresponding author

Published: 16 November 2005

BMC Genomics 2005, 6:161 doi:10.1|86/|47|-2|64-6-16|
Received: 16 August 2005

Accepted: 16 November 2005

This article is available from: http://www.biomedcentral.com/l47I-2164/6/161

(c) 2005 Jansa et al; licensee BioMed Central Ltd.

This is an Open Access article distributed under the terms of the Creative Commons Attribution License (http://creativecommons.org/licenses/by/2.0), which permits unrestricted use, distribution, and reproduction in any medium, provided the original work is properly cited.

\begin{abstract}
Background: The genome of classical laboratory strains of mice is an artificial mosaic of genomes originated from several mouse subspecies with predominant representation (>90\%) of the Mus $m$. domesticus component. Mice of another subspecies, East European/Asian Mus m. musculus, can interbreed with the classical laboratory strains to generate hybrids with unprecedented phenotypic and genotypic variations. To study these variations in depth we prepared the first genomic large insert BAC library from an inbred strain derived purely from the Mus $m$. musculus-subspecies. The library will be used to seek and characterize genomic sequences controlling specific monogenic and polygenic complex traits, including modifiers of dominant and recessive mutations.

Results: A representative mouse genomic BAC library was derived from a female mouse of the PWD/Ph inbred strain of Mus m. musculus subspecies. The library consists of 144768 primary clones from which $97 \%$ contain an insert of $120 \mathrm{~kb}$ average size. The library represents an equivalent of $6.7 \times$ mouse haploid genome, as estimated from the total number of clones carrying genomic DNA inserts and from the average insert size. The clones were arrayed in duplicates onto eight high-density membranes that were screened with seven single-copy gene probes. The individual probes identified four to eleven positive clones, corresponding to 6.9-fold coverage of the mouse genome. Eighty-seven BAC-ends of PWD/Ph clones were sequenced, edited, and aligned with mouse C57BL/6] (B6) genome. Seventy-three BAC-ends displayed unique hits on B6 genome and their alignment revealed 0.92 single nucleotide polymorphisms (SNPs) per $100 \mathrm{bp}$. Insertions and deletions represented $0.3 \%$ of the BAC end sequences.

Conclusion: Analysis of the novel genomic library for the PWD/Ph inbred strain demonstrated coverage of almost seven mouse genome equivalents and a capability to recover clones for specific regions of PWD/Ph genome. The single nucleotide polymorphism between the strains $\mathrm{PWD} / \mathrm{Ph}$ and $\mathrm{C} 57 \mathrm{BL} / 6 \mathrm{~J}$ was $0.92 / 100 \mathrm{bp}$, a value significantly higher than between classical laboratory strains. The library will serve as a resource for dissecting the phenotypic and genotypic variations between mice of the Mus m. musculus subspecies and classical laboratory mouse strains.
\end{abstract}




\section{Insert size distribution}

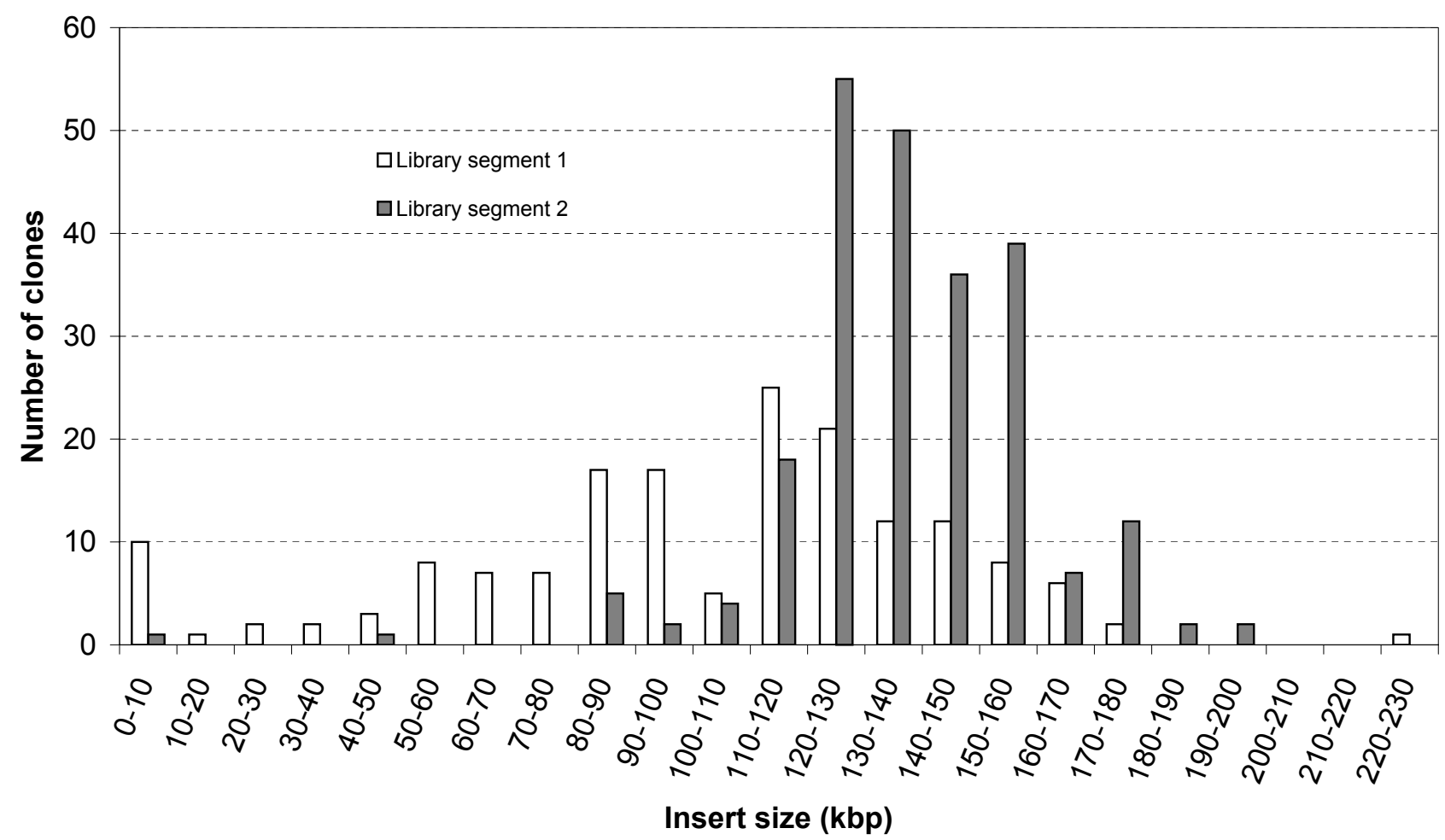

Figure I

Insert size distribution in two segments of the PWD/Ph BAC library. The segment I ( $\square$ ) represents $37.4 \%$ of the clones and its average insert size was I0I.I kb (SD \pm 21.4$)$. The segment 2 ( $\square$ ) represents $62.6 \%$ of the clones and its average insert size was $129.5 \mathrm{~kb}$ (SD \pm 14.7). The average insert size of the entire library was $120 \mathrm{~kb}$.

\section{Background}

$\mathrm{PWD} / \mathrm{Ph}$ is a highly inbred strain currently at 81 generations of brother $\times$ sister matings. It originated from the Mus m. musculus mouse subspecies by systematic inbreeding of a pair of wild mice trapped in $1972[1,2]$. The mouse subspecies M. m. musculus and M. m. domesticus diverged from their common ancestor about 300 thousand years [3] to 1 million years ago [4] and at present they display signs of incomplete reproductive isolation [57]. As a consequence of the interrupted gene flow between both subspecies, the mice of the $\mathrm{PWD} / \mathrm{Ph}$ strain exhibit a high degree of DNA polymorphisms and a broad range of phenotypic differences when compared to classical laboratory strains $[2,8]$. Because of this unique feature, the $\mathrm{PWD} / \mathrm{Ph}$ inbred strain has been nominated among 15 mouse strains, the genomes of which are being resequenced using high-density oligonucleotide array technology by Perlegen Sciences, Inc. [9]. Moreover, PWD/Ph serves as the chromosome donor strain in construction of a set of $\mathrm{C} 57 \mathrm{BL} / 6-\mathrm{Chr}^{\mathrm{PWD}}$ chromosome substitution strains (Gregorova, Forejt and coworkers, in preparation).
Bacterial Artificial Chromosome (BAC) genomic libraries are source of large genomic DNA insert clones for sequencing projects, physical mapping and isolation of intact genes $[10,11]$. Although BAC clones may carry large inserts of genomic DNA (up to $200 \mathrm{~kb}$ ) they display low rate of de novo rearrangements and are easy to handle. These features are in strong favor of the BAC libraries over the Yeast Artificial Chromosome (YAC) libraries, which can contain up to $60 \%$ of chimeric clones [12]. Transgenic mice can be generated using BAC clones to examine candidate genes in context of all regulatory DNA elements required for their function and the phenotype of a mutant mouse can be rescued by BAC transgenesis $[13,14]$. Moreover a targeted modification at exact positions within a genomic BAC clone can be introduced by recombineering $[15,16]$.

Here we report construction and characterization of the $\mathrm{PWD} / \mathrm{Ph}$ BAC library, the first genomic library of the Mus $m$. musculus mouse subspecies. This library together with the upcoming panel of chromosome substitution strains 
Table I: Hybridization of single-copy gene probes on high-density membrane

\begin{tabular}{|c|c|c|c|c|}
\hline Gene/Primer & GenBank accession/Primer sequence & Genomic position' & Length & Positive clones \\
\hline Mash & NM 008554 & & & \\
\hline mMashCgi-F & ACCCGGTTCCTCGCGAGCACTTTTC & chr7:130,673,330 & $358 \mathrm{bp}$ & $5 / 48$ \\
\hline mMashCgi-B & AGCGCAGCGTCTCCACCTTACTCAG & chr7:130,672,998 & & \\
\hline Adseverin & NM 009132 & & & \\
\hline CpG-Ads-IF & 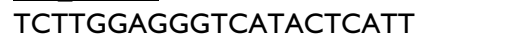 & $\operatorname{chr} \mid 2: 35,153,275$ & 516 bp & $7 / 48$ \\
\hline CpG-Ads-IR & GCAGCTCAAAATAATTACGAC & $\operatorname{chr} 12: 35,152,780$ & & \\
\hline $\lg 2 r$ & NM 010515 & & & \\
\hline $\lg 2 \mathrm{r}-\mathrm{H} 4 \mathrm{~F}$ & TCAGAACACTGGTGAGCAGTGGG & $\operatorname{chr} 17: 12,150,732$ & 244 bp & $1 \mathrm{l} / 48$ \\
\hline Igf2-H4R & GAGGGTAGGATTCCGTTGCAAGG & chrl7:12,150,509 & & \\
\hline \multirow[t]{3}{*}{ Tbp } & NM 013684 & & & \\
\hline & * probe derived from tbp-1942 clone & $\operatorname{chr} \mid 7: 14,324,440$ & 1085 bp & $4 / 48$ \\
\hline & & chr I $7: 14,334,524$ & & \\
\hline Usp26 & NM 031388 & & & \\
\hline Usp26-A & AATGTAACGAAGGGAGAAGTG & chrX:44, I0I,298 & 206 bp & $3 / 48$ \\
\hline Usp26-B & AGGCTTTTGCCTTCTTATCGAG & $\operatorname{chr} X: 44,101,113$ & & \\
\hline Xist & AY618354 & & & \\
\hline mXistF & AGTGGGTGTTCAGGGCGTGG & $\operatorname{chrX:94,885,925}$ & $293 \mathrm{bp}$ & $1 \mathrm{l} / 48$ \\
\hline mXistR & СТАTCСССТAGTCСTCTGCGG & $\operatorname{chrX:94,885,652}$ & & \\
\hline Tex/3 & NM 031381 & & & \\
\hline TexI3 pub-IF & ACCAGAGTTGGGAACAACTAA & 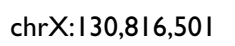 & $220 \mathrm{bp}$ & $7 / 48$ \\
\hline TexI3 pds-IR & CTGTTGTAGAGGGTAGAGGTT & $\operatorname{chrX:130,8|6,302}$ & & \\
\hline
\end{tabular}

I mm5 assembly, UCSC

will serve as a tool for analysis of complex traits by taking advantage of the evolutionary divergence between the two closely related mouse subspecies.

\section{Results and discussion Construction of the PWD/Ph-BAC library}

The BAC library was prepared by cloning the EcoRI-partially digested genomic DNA from the spleen of a PWD/ $\mathrm{Ph}$ female mouse in the vector pBACe3.6. Female DNA was chosen to gain an unbiased representation of the $\mathrm{X}$ chromosome in the library. The primary clones were picked and arrayed in 377 individual 384-well plates. The library consists of two segments containing 54144 and 90 624 clones, respectively. Together 144768 primary clones were arrayed on eight high-density nylon membranes (18 342 clones in doublets per membrane). The high-density membranes were utilized in subsequent hybridization experiments.

\section{Average insert size of the library}

The average insert size of the library was determined on a set of 400 randomly selected BAC clones. DNA samples were prepared from 164 and 236 BAC clones from the library segments 1 and 2, respectively, and subjected to NotI restriction analysis. The products of the digestion reactions were resolved by pulsed-field gel electrophoresis (PFGE) along with the high molecular weight markers. The average insert size for the first and the second library segment was $101.1 \mathrm{~kb}(\mathrm{SD} \pm 21.4)$ and $129.5 \mathrm{~kb}(\mathrm{SD} \pm$ 14.7), respectively (Figure 1). In the first and second library segments $6 \%$ and $1.2 \%$ clones were observed without insert, corresponding to $97 \%$ of insert-containing clones for the entire library. Estimation of 6.7-fold redundancy of the library was based on the average insert size $(120 \mathrm{~kb})$ and $2.6 \times 10^{9} \mathrm{bp}$ size of the mouse genome.

\section{Library screening and $B A C$ end sequencing}

A probability to find any given unique sequence in the library is $99.85 \%$, according to the published formula ( $\mathrm{P}$ $=1-\mathrm{e}^{\mathrm{N} \cdot \ln (1-\mathrm{I} / \mathrm{GS})}$, where $\mathrm{P}$ is probability, $\mathrm{N}$ is number of clones, I is insert size, and GS is size of genome) [17]. To further assess the genome redundancy and possible cloning bias of the library experimentally we performed a screening of the library with 7 single-copy gene probes. The probes were designed to amplify PCR products on the $\mathrm{PWD} / \mathrm{Ph}$ genomic DNA template (Table 1). Seven probes detected in total 48 positive clones by hybridization on 8 high-density library membranes, 4 to 11 clones for each individual probe. The average number of clones recognized by a single probe was 6.9 , in good accordance with the assessment of the library redundancy based on the average insert size.

To characterize the inserts of the PWD/Ph BAC library at the DNA sequence level we sequenced and manually edited 87 BAC ends from 47 BAC clones (total 38,339 nucleotides). The BAC end sequences (BESs) were masked for repeats and aligned on the C57BL/6J mouse genome. BES pairs of 29 BAC clones mapped to unique positions in the $\mathrm{B} 6$ genome on the opposite DNA strands within the 
Table 2: BAC end sequences of the positive clones mapped on the C57BL/6J genome

\begin{tabular}{|c|c|c|c|c|c|c|}
\hline \multirow[t]{2}{*}{ Gene } & \multirow[t]{2}{*}{ Probe position } & \multirow[t]{2}{*}{ BAC clone/primer } & \multirow[t]{2}{*}{ BES position } & \multirow[t]{2}{*}{ Strand } & \multicolumn{2}{|c|}{ Insert size (bp) } \\
\hline & & & & & mapped & PFGE \\
\hline \multirow[t]{2}{*}{ Mash } & chr7:130,672,998 & $327-5 \mathrm{I} / \mathrm{T7}$ & chr7:130,587,753 & + & 132,317 & 145,000 \\
\hline & & $327-51 / S P 6$ & chr7:130,720,069 & - & & \\
\hline \multirow[t]{4}{*}{ Ads } & $\operatorname{chr}|2: 35| 52,780$, & $262-11 \mathrm{G} / \mathrm{SP} 6$ & multiple hits & & n.d. & 105,000 \\
\hline & & 262-IIG/T7 & $\operatorname{chr} 12: 35,192,443$ & - & & \\
\hline & & $266-2 E / S P 6$ & $\operatorname{chr} 12: 35,090,782$ & + & 109,399 & 115,000 \\
\hline & & $266-2 \mathrm{E} / \mathrm{TT}$ & $\operatorname{chr} 12: 35,200,180$ & - & & \\
\hline \multirow[t]{6}{*}{$\lg 2 r$} & chrl7:12,150,509 & $279-51 / S P 6$ & $\operatorname{chr} 17: 12,057,702$ & + & 125,000 & 120,000 \\
\hline & & 279-5I/T7 & $\operatorname{chr}|7:| 2,|82,70|$ & - & & \\
\hline & & 282-5D/T7 & chrl 17:12,028,446 & + & 144,525 & 145,000 \\
\hline & & $282-5 \mathrm{D} / \mathrm{SP} 6$ & $\operatorname{chr} 17: 12,172,970$ & - & & \\
\hline & & 245-IIP/SP6 & $\operatorname{chr} 17: 12,000,500$ & + & 186,822 & 195,000 \\
\hline & & 245-IIP/T7 & $\operatorname{chr}|7:| 2,|87,32|$ & - & & \\
\hline \multirow[t]{2}{*}{$T b p$} & chr|7:14,324,440 & 297-21/T7 & chrl7:14,291,556 & + & 147,925 & 145,000 \\
\hline & & $297-21 / S P 6$ & $\operatorname{chr} 17: 14,439,480$ & - & & \\
\hline \multirow[t]{2}{*}{ Usp26 } & $\operatorname{chr} X: 44,101,113$ & 293-2IP/T7 & chrX:44,086,068 & + & 184,994 & 190,000 \\
\hline & & 293-2IP/SP6 & $\operatorname{chr} X: 44,271,06$ I & - & & \\
\hline \multirow[t]{6}{*}{ Xist } & $\operatorname{chrX:94,885,652}$ & $269-9 H / S P 6$ & $\operatorname{chr} X: 94,817,775$ & + & $|50,3| 4$ & 160,000 \\
\hline & & $269-9 \mathrm{H} / \mathrm{T} 7$ & $\operatorname{chrX:94,968,088}$ & - & & \\
\hline & & $255-3 \mathrm{~L} / \mathrm{TT}$ & chrX:94,756,622 & + & 134,724 & 145,000 \\
\hline & & $255-3 \mathrm{~L} / \mathrm{SP} 6$ & $\operatorname{chrX:94,891,345}$ & - & & \\
\hline & & $27 \mathrm{I}-12 \mathrm{~L} / \mathrm{SP} 6$ & $\operatorname{chrX:94,854,496}$ & + & 131,966 & 140,000 \\
\hline & & $27 I-12 L / T 7$ & chrX:94,986,46I & - & & \\
\hline \multirow[t]{4}{*}{$\operatorname{Tex} / 3$} & chrX:| $30,8 \mid 6,302$ & $257-22 \mathrm{~B} / \mathrm{SP} 6$ & chrX:| $30,76 \mid, 904$ & + & $|24,2| \mid$ & 120,000 \\
\hline & & 257-22B/T7 & chrX: $|30,886| \mid 4$, & - & & \\
\hline & & $322-4 J / S P 6$ & chrX: $|30,76|, 839$ & + & $|17,69|$ & 110,000 \\
\hline & & 322-4J/T7 & chrX: $130,879,529$ & - & & \\
\hline
\end{tabular}

BAC ends (BESs) of the positive clones identified on the membranes no. 6 and no. 7 were sequenced, mapped and aligned to the mouse genome ( $\mathrm{mm} 5$ assembly, UCSC). The coordinates on the mouse genome are shown for the probes as well as for the ends of genomic inserts. An average insert size $140.8 \mathrm{~kb}$ was calculated from mapped positions and $141.2 \mathrm{~kb}$ was determined by pulsed-field gel electrophoresis (PFGE).

distance up to $200 \mathrm{~kb}$ (Additional file 1). The mapping allowed us to estimate the average insert size of the BAC clones based on their locations on the $\mathrm{B} 6$ genome as 127 $\mathrm{kb}$, which was slightly higher estimate than the average insert size acquired by restriction analysis $(120 \mathrm{~kb})$. These values corresponded well with the average insert size calculated for another set of clones recovered by the library screening described above (Table 2). A BES pair belonging to the clone 307-90 mapped to two distinct chromosomes. Whether it represents a chimeric insert or a chromosomal rearrangement in the $\mathrm{PWD} / \mathrm{Ph}$ genome remains to be determined by fluorescence in situ hybridization (FISH) analysis. For each of the additional 13 BAC clones we found unambiguous positions for only one BES of a pair. Mapping of remaining 14 BESs was prevented by a high content of repetitive elements.

\section{Analysis of SNPs and DNA polymorphism}

To find out the degree of nucleotide polymorphism between the $\mathrm{PWD} / \mathrm{Ph}$ and $\mathrm{C} 57 \mathrm{BL} / 6 \mathrm{~J}$ mouse strains, we aligned 73 uniquely mapped BESs $(32,182$ nucleotides) with their C57BL/6J genomic counterparts and found 297 single nucleotide substitutions. The calculated SNP rate 0.92 per $100 \mathrm{bp}$ is significantly higher than SNP frequency between laboratory strains [18-20] and corresponds well to the rate between the closely related subspecies Mus $\mathrm{m}$. molossinus and the C57BL/6J strain $(0.96 \%)$ [21]. The insertions and deletions (indels) were found with lower frequency than SNPs: single nucleotide indels occurred with frequency $0.19 \%$ while multinucleotide indels with only $0.08 \%$ frequency. All nucleotide changes observed in the alignments of $87 \mathrm{PWD} / \mathrm{Ph} \mathrm{BESs}$ and their $\mathrm{B} 6$ counterparts are summarized in Additional files 2 and 3. The high number of SNPs of the PWD/Ph strain is reflected by a high frequency of genetic and phenotypic variations between $\mathrm{PWD} / \mathrm{Ph}$ and $\mathrm{B} 6$ inbred mice. An initial study performed to compare behavior of the $\mathrm{PWD} / \mathrm{Ph}$ inbred strain with the $\mathrm{B} 6$ revealed substantial behavioral differences between these two strains [8]. Using dense SNP maps of various laboratory and wild-derived inbred 
strains $[20,22]$ it will be possible to map genes responsible for particular complex traits more efficiently. For ultimate validation of candidate genes genomic BAC libraries will be highly desirable.

\section{Conclusion}

The first genomic BAC library was constructed for the Mus m. musculus subspecies of the house mouse, represented by the PWD/Ph inbred strain. The quality of the PWD BAC library was verified by hybridization with seven unique probes that identified multiple positive clones. BAC end sequencing provided a new piece of evidence on the high incidence of SNPs $(0.92 / 100 \mathrm{bp})$ between C57BL/6J and PWD/Ph inbred strains. The mouse PWD/ Ph BAC library will serve as a tool for functional genomics of complex genetic traits with the ultimate goal to identify and clone responsible genes. The PWD BAC library will become accessible to the scientific community via RZPD, Berlin, Germany [23].

\section{Methods}

\section{Mouse strain and DNA isolation}

Mouse manipulation was in accordance with the Czech Animal Protection Act No. 246/92, 162/93, and decrees No. 311/97, fully compatible with the NIH Publication No. 85-23, revised 1985. A female mouse of the PWD/Ph inbred strain, derived from the Mus mus musculus subspecies [2] was used for high molecular weight DNA (HMW-DNA) preparation. The mouse was killed by cervical dislocation, spleen dissected and single cell suspension prepared in PBS using a glass homogenizer. The agarose-embeded HMW-DNA was prepared as described in detail elsewhere [24].

\section{Library construction}

The agarose HMW-DNA plugs were subjected to pre-electrophoresis in a CHEF-DR-III apparatus (BioRad) in 1\% agarose and $0.5 \times$ TBE buffer for $12 \mathrm{hrs}(4 \mathrm{~V} / \mathrm{cm}, 5 \mathrm{~s}$ pulse, $\left.14^{\circ} \mathrm{C}\right)$. Genomic DNA was partially digested with the mixture of EcoRI endonuclease and EcoRI methylase. The optimal ratio of the enzymes was determined by titration: usually 5-25 units of methylase per 1 unit of endonuclease were employed. DNA fragments were prepared by slight modification of an approach described before [24]. Briefly, DNA fragments were separated from the digested agarose plugs in the CHEF-DR-III in $1 \%$ agarose and $0.5 \times$ TBE buffer for $16 \mathrm{hrs}\left(5 \mathrm{~V} / \mathrm{cm}, 0.1\right.$ to $40 \mathrm{~s}$ pulse, $\left.14^{\circ} \mathrm{C}\right)$. Subsequently, three stripes corresponding to fragment size between $150 \mathrm{~kb}$ and $200 \mathrm{~kb}$ were excised and subjected to another size selection by additional electrophoresis in $0.5 \times$ TBE buffer for $12 \mathrm{hr}(5 \mathrm{~V} / \mathrm{cm}, 2.5$ to 4.5 $s$ pulse, $14^{\circ} \mathrm{C}$ ). The second size selection effectively removed short fragments while keeping long fragments in the agarose strips. The appropriate fragments were isolated by electroelution and ligated to the EcoRI site of the
pBACe3.6 vector [25]. The ligation mixtures were dialyzed on ice in a well created by $0.5 \%$ agarose with $1 \mathrm{M}$ glucose for $1 \mathrm{hr}$. The desalted ligation mixtures were electroporated into E. coli electrocompetent DH10B ElectroMax cells (Invitrogen) by a Gene Pulser apparatus (BioRad) in $0.1 \mathrm{~cm}$ cuvette with the following parameters: voltage 1.8 $\mathrm{V}$, impedance $200 \Omega$, capacitance $25 \mu \mathrm{F}$, time constant between 3.5 to $4.5 \mathrm{~s}$. The electroporated cells were diluted in $1 \mathrm{ml}$ SOC medium and incubated in an orbital shaker at $37^{\circ} \mathrm{C}$ and $200 \mathrm{rpm}$ for $1 \mathrm{hr}$. The titer of each electroporation reaction was determined by spreading an aliquot on selection agar plates (LB, $20 \mu \mathrm{g} / \mathrm{ml}$ chloramphenicol, $5 \%$ sucrose) as described [24]. The remainder containing the primary clones was supplemented with glycerol to the final concentration of $15 \%$, then quickly frozen in liquid nitrogen and stored at $-80^{\circ} \mathrm{C}$. The frozen stocks of the primary clones were recovered and spread on large selection plates. The colonies were picked with multi-functional robotical system Gene TacTM-G3 (Genomic Solutions) and arrayed in 377 individual 384-well dishes containing LB medium supplied by $7.5 \%$ glycerol and $20 \mu \mathrm{g} / \mathrm{ml}$ chloramphenicol. The clones were gridded using the robot on 8 nylon membranes (18 342 unique clones in duplicates per membrane). Afterwards, the bacterial colonies were lysed, their DNA denatured, and crosslinked to the membranes by standard methods [26].

\section{Estimation of average insert size}

One hundred sixty-two clones from the library segment 1 and 236 clones from the segment 2 were randomly picked and grown in $15 \mathrm{ml}$ 2xYT medium (16 g/L tryptone, $10 \mathrm{~g} /$ $\mathrm{L}$ yeast extract, $5 \mathrm{~g} / \mathrm{L} \mathrm{NaCl}, 20 \mu \mathrm{g} / \mathrm{ml}$ chloramphenicol) at $37^{\circ} \mathrm{C}$ and $300 \mathrm{rpm}$ for $18-20 \mathrm{~h}$. BAC DNA was prepared using a modification of the standard protocol based on alkalic lysis. Briefly, $15 \mathrm{ml}$ of the overnight culture was spun down, the bacterial pellet was resuspended in $300 \mu \mathrm{l}$ of lysis buffer I ( $50 \mathrm{mM}$ glucose, $25 \mathrm{mM}$ Tris- $\mathrm{HCl}$ with $\mathrm{pH}$ $=8.0,10 \mathrm{mM}$ EDTA), then lysed with $600 \mu \mathrm{l}$ of freshly made lysis buffer II (0.2 M NaOH, 1\% SDS) and precipitated with $450 \mu \mathrm{l}$ of lysis buffer III ( $3 \mathrm{M}$ KOAc, $\mathrm{pH}=4.8$ ) followed by incubation on ice for 1 hour. The resulted precipitate was spun down in a microfuge for $15 \mathrm{~min}$ at maximum speed. The BAC DNA was further precipitated at room temperature with 0.6 volumes of isopropanol for $30 \mathrm{~min}$ and centrifuged at maximum speed for $10 \mathrm{~min}$. The pellet was washed with $70 \%$ ethanol, air dried shortly and dissolved in $25 \mu \mathrm{l}$ of TE. The BAC DNA was subjected to NotI (Fermentas) restriction overnight to achieve complete digestion. The reactions were resolved along with the mid range PFG marker I (New England Biolabs, cat \# N3551S) in the CHEF-DR-III in $1 \%$ agarose and $0.5 \times$ TBE buffer for $16 \mathrm{hrs}\left(5 \mathrm{~V} / \mathrm{cm}, 0.1\right.$ to $40 \mathrm{~s}$ pulse, $\left.14^{\circ} \mathrm{C}\right)$. The insert size was estimated after ethidium bromide staining and the average insert size for both segments of the library was calculated. 


\section{Hybridization of high-density colony filters}

Seven probes for single-copy mouse genes were used to screen the library on high-density membranes. Six of them were produced by PCR on 50 ng of HMW-DNA isolated from the brain of a female $\mathrm{PWD} / \mathrm{Ph}$ mouse. The primers were designed using Oligo 6 (MBI) software and the GenBank mRNA sequences (Table 1). PCR was performed at standard conditions: $96^{\circ} \mathrm{C}$ for $1 \mathrm{~min}, 30$ cycles at $96^{\circ} \mathrm{C}$ for $10 \mathrm{~s}, 58^{\circ} \mathrm{C}$ for $20 \mathrm{~s}, 72^{\circ} \mathrm{C}$ for $1 \mathrm{~min}$, and final extension at $72^{\circ} \mathrm{C}$ for $3 \mathrm{~min}$. The 1085 -bp DNA fragment of Tbp ( $\underline{\mathrm{U} 63933}$ ) was derived from the tbp-1942 cDNA clone (kind gift from Dr. Trachtulec) [27]. The resulted amplicons and Tbp fragment were purified and labeled by random priming with $\left[\alpha-{ }^{32} \mathrm{P}\right] \mathrm{dCTP}$. Hybridization was done in Church buffer [28] with $15 \%$ formamide at $60^{\circ} \mathrm{C}$ over night. The membranes were washed in $0.2 \times \mathrm{SSC}$, $0.1 \%$ SDS buffer at $42^{\circ} \mathrm{C}$ for $20 \mathrm{~min}$ and then in $0.2 \times$ SSC, $0.1 \%$ SDS buffer at $60^{\circ} \mathrm{C}$ for $10 \mathrm{~min}$. The membranes were then autoradiographed for 2 to 10 days, the positive clones identified and recovered from the frozen 384-well plates.

\section{$B A C$ end sequencing and analysis}

BAC DNA was prepared from 60 clones as described above and purified using a QIAGEN kit following the manufacturer's instructions. The sequencing was performed using a Big Dye Terminator v3.1 cycle sequencing kit in an ABI 310 instrument (Applied Biosystems) with primers T7 (GGTCGAGCTTGACATTGTAG) and SP6 (GATCCTCCCGAATTGACTAGTG). Each DNA sample was sequenced twice. The sequences from the same BAC end were aligned and manually edited in order to obtain a consensus sequence. BESs were masked for mouse repeats using RepeatMasker [29] (sensitive settings) and aligned to the mouse genome sequence (mm5 assembly, May 2004, UCSC) [30,31] using BLAT [32]. The mouse genome sequence had already been soft-masked for repeats by UCSC and BLAT was set to produce all possible alignments (tile size $=10$, minimum score $=0$, minimum sequence identity $=0$ ). The hits were filtered to keep only those with minimum alignment ratio $=0.8$. After manual inspection, a list of BESs mapped to unambiguous positions in the genome was compiled. The corresponding genomic sequences were excised and aligned with the appropriate BESs (unmasked sequence) using SSEARCH [33] (standard settings). A Perl script was written to process the pair-wise alignments and enumerate the sequence polymorphisms (SNPs, insertions, deletions, etc). The visualization of DNA polymorphisms was made by TeXshade LaTeX package [34]. All intermediate steps were performed using customized Perl scripts and utilities available from UCSC website [35].

\section{Authors' contributions}

PJ constructed the library, participated in the sequence alignment and drafted the manuscript with JF and PD. PD carried out the sequence alignments and the analysis of DNA polymorphism. JF conceived the study, participated in its design and coordination. PJ and JF wrote the manuscript and all authors read and approved its final version.

\section{Additional material}

\section{Additional file 1}

$B A C$ end sequences mapped on $C 57 B L / 6$ mouse genome.

Click here for file

[http://www.biomedcentral.com/content/supplementary/1471-

2164-6-161-S1.xls]

\section{Additional file 2}

Summary of polymorphisms detected in 73 BAC end sequences. Click here for file

[http://www.biomedcentral.com/content/supplementary/1471-

2164-6-161-S2.xls]

\section{Additional file 3}

Polymorphisms detected in 73 BAC end sequences.

Click here for file

[http://www.biomedcentral.com/content/supplementary/1471-

2164-6-161-S3.pdf]

\section{Acknowledgements}

We thank Heinz Himmelbauer for invaluable help at the start of the project, Jaroslav Doležel for the access to the core facility of his laboratory, Jaroslav Janda, Michaela Libošvárová and Radka Tusková for help with picking and gridding the library, Vladana Fotopulosová for help with DNA sequencing, and Zdeněk Trachtulec and Šárka Takáčová for reading the manuscript. This work was supported by the Ministry of Education, Youth and Sports of the Czech Republic Grant No. IM6837805002 - Center for Applied Genomics, by the Grant Agency of the Academy of Sciences Grant AVOZ505205 I4 and by NIH grant IROI HG003 I8. Jiři Forejt was supported as an International Scholar of the Howard Hughes Medical Institute by Grant 55000306.

\section{References}

I. Pavljukova H, Forejt J: Private communication. Mouse News Lett I98I, 65:44.

2. Gregorova S, Forejt J: PWD/Ph and PWK/Ph inbred mouse strains of Mus $\mathrm{m}$. musculus subspecies--a valuable resource of phenotypic variations and genomic polymorphisms. Folia Biol (Praha) 2000, 46:31-4I.

3. Boursot P, Din W, Anand R, Darviche D, Dod B, VonDeimling F, Talwar GP, Bonhomme $F$ : Origin and radiation of the house mouse: Mitochondrial DNA phylogeny. Journal of Evolutionary Biology 1996, 9, 391-4I5.:39|-4I5.

4. Silver LM: Mouse Genetics Concepts and Applications. In Concepts and Applications, Oxford University Press; 1995:376.

5. Forejt J, Ivanyi P: Genetic studies on male sterility of hybrids between laboratory and wild mice (Mus musculus L.). Genet Res 1974, 24: | 89-206.

6. Forejt J: Hybrid sterility in the mouse. Trends Genet 1996, 12:412-417. 
7. Storchova R, Gregorova S, Buckiova D, Kyselova V, Divina P, Forejt $\mathrm{J}$ : Genetic analysis of $\mathbf{X}$-linked hybrid sterility in the house mouse. Mamm Genome 2004, 15:5 I5-524.

8. Fernandes C, Liu L, Paya-Cano JL, Gregorova S, Forejt J, Schalkwyk LC: Behavioral Characterization of Wild Derived Male Mice (Mus musculus musculus) of the PWD/Ph Inbred Strain: High Exploration Compared to C57BL/6J. Behav Genet 2004, 34:621-630.

9. Perlegen Sciences, Inc. [http://www.perlegen.com/]

10. Osoegawa K, Zhu B, Shu CL, Ren T, Cao Q, Vessere GM, Lutz MM, Jensen-Seaman MI, Zhao S, de Jong PJ: BAC resources for the rat genome project. Genome Res 2004, I4:780-785.

II. McPherson JD, Marra M, Hillier L, Waterston RH, Chinwalla A, Wallis J, Sekhon M, Wylie K, Mardis ER, Wilson RK, Fulton R, Kucaba TA, Wagner-McPherson C, Barbazuk WB, Gregory SG, Humphray SJ, French L, Evans RS, Bethel G, Whittaker A, Holden JL, McCann OT, Dunham A, Soderlund C, Scott CE, Bentley DR, Schuler G, Chen HC, Jang W, Green ED, Idol JR, Maduro VV, Montgomery KT, Lee E, Miller A, Emerling S, Kucherlapati, Gibbs R, Scherer S, Gorrell JH, Sodergren E, Clerc-Blankenburg K, Tabor P, Naylor S, Garcia D, de Jong PJ, Catanese JJ, Nowak N, Osoegawa K, Qin S, Rowen L, Madan A, Dors M, Hood L, Trask B, Friedman C, Massa H, Cheung VG, Kirsch IR, Reid T, Yonescu R, Weissenbach J, Bruls T, Heilig R, Branscomb E, Olsen A, Doggett N, Cheng JF, Hawkins T, Myers RM, Shang J, Ramirez L, Schmutz J, Velasquez O, Dixon K, Stone NE, Cox DR, Haussler D, Kent WJ, Furey T, Rogic S, Kennedy S, Jones S, Rosenthal A, Wen G, Schilhabel M, Gloeckner G, Nyakatura G, Siebert R, Schlegelberger B, Korenberg J, Chen XN, Fujiyama A, Hattori M, Toyoda A, Yada T, Park HS, Sakaki Y, Shimizu N, Asakawa S, Kawasaki K, Sasaki T, Shintani A, Shimizu A, Shibuya K, Kudoh J, Minoshima S, Ramser J, Seranski P, Hoff C, Poustka A, Reinhardt R, Lehrach H: A physical map of the human genome. Nature 200I, 409:934-94I.

12. Banfi S, Ledbetter SA, Chinault AC, Zoghbi HY: An easy and rapid method for the detection of chimeric yeast artificial chromosome clones. Nucleic Acids Res 1992, 20:1814.

13. Antoch MP, Song EJ, Chang AM, Vitaterna MH, Zhao Y, Wilsbacher LD, Sangoram AM, King DP, Pinto LH, Takahashi JS: Functional identification of the mouse circadian Clock gene by transgenic BAC rescue. Cell 1997, 89:655-667.

14. Abe K, Hazama M, Katoh H, Yamamura K, Suzuki M: Establishment of an efficient BAC transgenesis protocol and its application to functional characterization of the mouse Brachyury locus. Exp Anim 2004, 53:3 II-320.

15. Lee EC, Yu D, Martinez de Velasco J, Tessarollo L, Swing DA, Court DL, Jenkins NA, Copeland NG: A highly efficient Escherichia coli-based chromosome engineering system adapted for recombinogenic targeting and subcloning of BAC DNA. Genomics 200I, 73:56-65.

16. Gong S, Yang XW, Li C, Heintz N: Highly efficient modification of bacterial artificial chromosomes (BACs) using novel shuttle vectors containing the R6Kgamma origin of replication. Genome Res 2002, I 2:1992-1998.

17. Clarke L, Carbon J: A colony bank containing synthetic Col EI hybrid plasmids representative of the entire E. coli genome. Cell 1976, 9:91-99.

18. Lindblad-Toh K, Winchester E, Daly MJ, Wang DG, Hirschhorn JN, Laviolette JP, Ardlie K, Reich DE, Robinson E, Sklar P, Shah N, Thomas D, Fan JB, Gingeras T, Warrington J, Patil N, Hudson TJ, Lander ES: Large-scale discovery and genotyping of single-nucleotide polymorphisms in the mouse. Nat Genet 2000, 24:38I-386.

19. Wiltshire T, Pletcher MT, Batalov S, Barnes SW, Tarantino LM, Cooke MP, Wu H, Smylie K, Santrosyan A, Copeland NG, Jenkins NA, Kalush F, Mural RJ, Glynne RJ, Kay SA, Adams MD, Fletcher CF: Genome-wide single-nucleotide polymorphism analysis defines haplotype patterns in mouse. Proc Natl Acad Sci U S A 2003, 100:3380-3385.

20. Frazer KA, Wade CM, Hinds DA, Patil N, Cox DR, Daly MJ: Segmental phylogenetic relationships of inbred mouse strains revealed by fine-scale analysis of sequence variation across $4.6 \mathrm{mb}$ of mouse genome. Genome Res 2004, I 4: I493-I500.

21. Abe K, Noguchi H, Tagawa K, Yuzuriha M, Toyoda A, Kojima T, Ezawa K, Saitou N, Hattori M, Sakaki Y, Moriwaki K, Shiroishi T: Contribution of Asian mouse subspecies Mus musculus molossinus to genomic constitution of strain C57BL/6J, as defined by BAC-end sequence-SNP analysis. Genome Res 2004, I 4:2439-2447.
22. Pletcher MT, McClurg P, Batalov S, Su Al, Barnes SW, Lagler E, Korstanje R, Wang X, Nusskern D, Bogue MA, Mural RJ, Paigen B, Wiltshire $T$ : Use of a dense single nucleotide polymorphism map for in silico mapping in the mouse. PLoS Biol 2004, 2:e393.

23. RZPD, Berlin, Germany [http://www.rzpd.de/]

24. Osoegawa K, de Jong PJ, Frengen E, loannou PA: Construction of Bacterial Arteficial Chromosome (BAC/PAC) Librarries. In Current Protocols in Molecular Biology Volume I. Edited by: Ausubel FM, Brent R, Kingston RE, Moore DD, Seidman JG, Smith JA and Struhl K. , John Wiley \& Sons, Inc; 200I:5.9.1-5.9.33.

25. Frengen E, Weichenhan D, Zhao B, Osoegawa K, van Geel M, de Jong PJ: A modular, positive selection bacterial artificial chromosome vector with multiple cloning sites. Genomics 1999, 58:250-253

26. Ausubel FM, Brent R, Kingston RE, Moore DD, Seidman JG, Smith JA, Struhl K: Current Protocols in Molecular Biology. Edited by: Chanda VB. , John Wiley \& Sons, Inc.; 2005.

27. Trachtulec Z, Hamvas RM, Forejt J, Lehrach HR, Vincek V, Klein J: Linkage of TATA-binding protein and proteasome subunit C5 genes in mice and humans reveals synteny conserved between mammals and invertebrates. Genomics 1997, 44:1-7.

28. Church GM, Gilbert W: Genomic sequencing. Proc Natl Acad Sci U SA 1984, 81:1991-1995.

29. Smit AF, Hubley R, Green P: RepeatMasker Open-3.0. [http:// www.repeatmasker.org/].

30. Karolchik D, Baertsch R, Diekhans M, Furey TS, Hinrichs A, Lu YT, Roskin KM, Schwartz M, Sugnet CW, Thomas DJ, Weber RJ, Haussler D, Kent WJ: The UCSC Genome Browser Database. Nucleic Acids Res 2003, 31:51-54.

3I. Waterston RH, Lindblad-Toh K, Birney E, Rogers J, Abril JF, Agarwal P, Agarwala R, Ainscough R, Alexandersson M, An P, Antonarakis SE, Attwood J, Baertsch R, Bailey J, Barlow K, Beck S, Berry E, Birren B, Bloom T, Bork P, Botcherby M, Bray N, Brent MR, Brown DG, Brown SD, Bult C, Burton J, Butler J, Campbell RD, Carninci P, Cawley S, Chiaromonte F, Chinwalla AT, Church DM, Clamp M, Clee C, Collins FS, Cook LL, Copley RR, Coulson A, Couronne O, Cuff J, Curwen V, Cutts T, Daly M, David R, Davies J, Delehaunty KD, Deri J, Dermitzakis ET, Dewey C, Dickens NJ, Diekhans M, Dodge S, Dubchak I, Dunn DM, Eddy SR, Elnitski L, Emes RD, Eswara P, Eyras E, Felsenfeld A, Fewell GA, Flicek P, Foley K, Frankel WN, Fulton LA, Fulton RS, Furey TS, Gage D, Gibbs RA, Glusman G, Gnerre S, Goldman N, Goodstadt L, Grafham D, Graves TA, Green ED, Gregory S, Guigo R, Guyer M, Hardison RC, Haussler D, Hayashizaki Y, Hillier LW, Hinrichs A, Hlavina W, Holzer T, Hsu F, Hua A, Hubbard T, Hunt A, Jackson I, Jaffe DB, Johnson LS, Jones M, Jones TA, Joy A, Kamal M, Karlsson EK, Karolchik D, Kasprzyk A, Kawai J, Keibler E, Kells C, Kent WJ, Kirby A, Kolbe DL, Korf I, Kucherlapati RS, Kulbokas EJ, Kulp D, Landers T, Leger JP, Leonard S, Letunic I, Levine R, Li J, Li M, Lloyd C, Lucas S, Ma B, Maglott DR, Mardis ER, Matthews L, Mauceli E, Mayer JH, McCarthy M, McCombie WR, McLaren S, McLay K, McPherson JD, Meldrim J, Meredith B, Mesirov JP, Miller W, Miner TL, Mongin E, Montgomery KT, Morgan M, Mott R, Mullikin JC, Muzny DM, Nash WE, Nelson JO, Nhan MN, Nicol R, Ning Z, Nusbaum C, O'Connor MJ, Okazaki Y, Oliver K, Overton-Larty E, Pachter L, Parra G, Pepin $\mathrm{KH}$, Peterson J, Pevzner P, Plumb R, Pohl CS, Poliakov A, Ponce TC, Ponting CP, Potter S, Quail M, Reymond A, Roe BA, Roskin KM, Rubin EM, Rust AG, Santos R, Sapojnikov V, Schultz B, Schultz J, Schwartz MS, Schwartz S, Scott C, Seaman S, Searle S, Sharpe T, Sheridan A, Shownkeen R, Sims S, Singer JB, Slater G, Smit A, Smith DR, Spencer B, Stabenau A, Stange-Thomann N, Sugnet C, Suyama M, Tesler G, Thompson J, Torrents D, Trevaskis E, Tromp J, Ucla C, Ureta-Vidal A, Vinson JP, Von Niederhausern AC, Wade CM, Wall M, Weber RJ, Weiss RB, Wendl MC, West AP, Wetterstrand K, Wheeler R, Whelan S, Wierzbowski J, Willey D, Williams S, Wilson RK, Winter E, Worley KC, Wyman D, Yang S, Yang SP, Zdobnov EM, Zody MC, Lander ES: Initial sequencing and comparative analysis of the mouse genome. Nature 2002, 420:520-562.

32. Kent WJ: BLAT--the BLAST-like alignment tool. Genome Res 2002, I 2:656-664.

33. Pearson WR: Flexible sequence similarity searching with the FASTA3 program package. Methods Mol Biol 2000, I32:185-219.

34. Beitz $E$ : TEXshade: shading and labeling of multiple sequence alignments using LATEX2 epsilon. Bioinformatics 2000, 16:135-139.

35. UCSC Genome Browser, Jim Kent's Web Page [http:// www.soe.ucsc.edu/ kent/] 